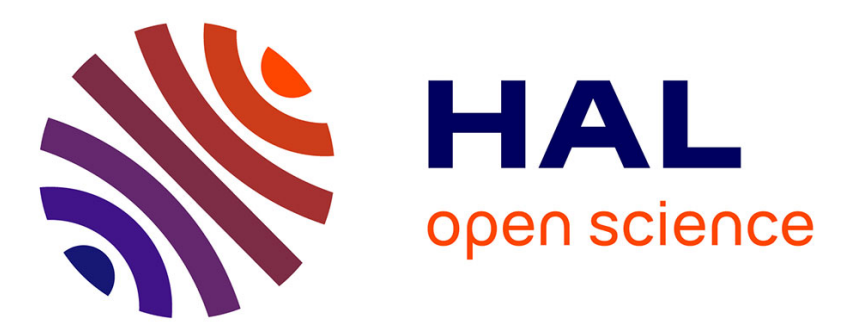

\title{
Porcine circovirus type 2 (PCV2) antigen localisation and post-weaning multisystemic wasting syndrome (PMWS) in free-ranging wild boar ( ssp ) in Italy
}

Federico Morandi, Ranieri Verin, Giuseppe Sarli, Nicola Canetti, Marianne Scacco, Serena Panarese, Alessandro Poli

\section{To cite this version:}

Federico Morandi, Ranieri Verin, Giuseppe Sarli, Nicola Canetti, Marianne Scacco, et al.. Porcine circovirus type 2 (PCV2) antigen localisation and post-weaning multisystemic wasting syndrome (PMWS) in free-ranging wild boar ( ssp ) in Italy. European Journal of Wildlife Research, 2010, 56 (5), pp.717-724. 10.1007/s10344-010-0365-1 . hal-00565434

\section{HAL Id: hal-00565434 \\ https://hal.science/hal-00565434}

Submitted on 13 Feb 2011

HAL is a multi-disciplinary open access archive for the deposit and dissemination of scientific research documents, whether they are published or not. The documents may come from teaching and research institutions in France or abroad, or from public or private research centers.
L'archive ouverte pluridisciplinaire HAL, est destinée au dépôt et à la diffusion de documents scientifiques de niveau recherche, publiés ou non, émanant des établissements d'enseignement et de recherche français ou étrangers, des laboratoires publics ou privés. 


\title{
Porcine circovirus type 2 (PCV2) antigen localisation and post-weaning multisystemic wasting syndrome (PMWS) in free-ranging wild boar (Sus scrofa ssp scrofa) in Italy
}

\author{
Federico Morandi • Ranieri Verin - Giuseppe Sarli • \\ Nicola Canetti • Marianne Scacco • Serena Panarese • \\ Alessandro Poli
}

Received: 3 June 2009 /Revised: 9 October 2009 / Accepted: 13 January 2010 /Published online: 13 February 2010

(C) Springer-Verlag 2010

\begin{abstract}
Wild boar (Sus scrofa ssp scrofa) is a host of porcine circovirus 2 (PCV-2), and infection in this species has been reported in many countries. This study sampled tissues from 348 wild boars in Italy in the provinces of Bologna, Padua and Pisa. No clinical signs or macroscopic lesions were recorded in the sampled animals. Immunolocalisation for PCV-2 was performed on tissues, and viral antigen was disclosed in 38 animals, 11 immunohistochemistry (IHC) positive out of $148(7.43 \%)$ sampled in northern Italy and 27 immunofluorescence (IF) positive out of 200 $(13.5 \%)$ sampled in central Italy, respectively. Histologically, 19 cases displayed post-weaning multisystemic wasting syndrome (PMWS) histological lesions, but PCV2 was only proved in nine of them (three from Bologna and Padua
\end{abstract}

Communicated by F.-J. Kaup

F. Morandi $(\bowtie) \cdot$ G. Sarli $\cdot$ S. Panarese

Department of Veterinary Public Health and Animal Pathology,

University of Bologna,

via Tolara di Sopra, 50-40064 Ozzano Emilia,

Bologna, Italy

e-mail: federico.morandi@unibo.it

R. Verin · A. Poli

Department of Animal Pathology, University of Pisa,

Viale delle Piagge 2,

56124 Pisa, Italy

N. Canetti

via dell'Alva,

13-40036 Monzuno, Bologna, Italy

M. Scacco

Istituto Superiore per la Protezione e la Ricerca

Ambientale (ex INFS),

Via Ca Fornacetta 9-40064 Ozzano Emilia,

Bologna, Italy by IHC and six from Pisa by IF). Animals aged 7 to 8 months were the most affected by PCV2 infection, suggesting an important role of this age class in the epidemiology of the virosis in the tested populations. Moreover, the study confirmed that wild boar can be a host of PCV-2, and showed that the virus and PMWS is widespread and endemic in wild boar in Italy as in other countries.

Keywords PCV2 . Wild boar (Sus scrofa ssp scrofa). Immunohistochemistry · Immunofluorescence · PMWS

\section{Introduction}

Porcine circovirus type 2 (PCV2) was first reported in Canada (Harding 1996) associated with a wasting disease called post-weaning multisystemic wasting syndrome (PMWS) of swine. Since then, a number of swine conditions have been linked to PCV2 infection now known as porcine circovirus type 2-associated diseases (PCVAD) (Oppriessnig et al. 2007): porcine dermatitis and nephropathy syndrome, porcine respiratory diseases complex, proliferative and necrotising pneumonia, reproductive disorders, necrotising lymphadenitis and granulomatous enteritis (Harding 2004; Oppriessnig et al. 2007; Segalés et al. 2004). Other viruses (namely porcine reproductive and respiratory syndrome virus, porcine parvovirus, swine influenza virus and Aujeszky's disease virus) and bacteria (Mycoplasma hyopneumoniae, Lawsonia intracellularis and Pasteurella multocida) have been attributed an important role in the pathogenesis of PCVAD (Oppriessnig et al. 2007).

PCV2 has a mainly horizontal transmission (both direct and indirect) in the pig by oro-nasal secretions, 
faeces and urine (Ghebremariam and Gruys 2005), but a vertical transmission has also been described (Park et al. 2005). The PCV2 host range is limited to the genus Sus (Segalés et al. 2005) comprising both wild boar and domestic pigs. Serological surveys (Rose et al. 2002), immunohistochemistry (IHC) (Ghebremariam and Gruys 2005; Sarli et al. 2009) and in situ hybridization (ISH) (Ghebremariam and Gruys 2005) show that PCV2 is ubiquitous and may be encountered in herds both with and without PMWS. Wild boar (Sus scrofa ssp scrofa) can also be infected by PCV2 (Hungary, Cságola et al. 2006; Belgium, Sanchez et al. 2001; Slovenia, Toplak et al. 2004; Spain, Vicente et al. 2004; Germany, Knell et al. 2005) and suffer from PMWS (Canada, Ellis et al. 2003; Germany, Schulze et al. 2004; Brasil, Correa et al. 2006; Croatia, Lipej et al. 2007; Greece, Sofia et al. 2008). Serological surveys in wild boar also provide a high and diffuse seroprevalence ranging from $23 \%$ to $58 \%$ in Spain (Vicente et al. 2004), 35.6\% in Belgium (Sanchez et al. 2001), 43\% in Czech Republic (Sedlak et al. 2008) and $39.8 \%$ in Italy (Delogu et al. 2008). A PCR tested pool of organs from wild boar were found positive in Hungary (20.5\%; Cságola et al. 2006) and spleens in subjects from Slovenia (25\%; Toplak et al. 2004).

PMWS clinical signs and macroscopic and microscopic lesions in wild boar (Schulze et al. 2004) are the same as those described in domestic pigs (Segalés et al. 2005): clinical signs are variable weight loss, respiratory distress, pallor of the skin and evidence of macroscopical wasting, lymph node enlargement and non-collapsed rubbery lungs. Microscopic lesions include lymphocyte depletion in lymphoid tissues with diffuse histiocytic infiltration and occasionally epithelioid cells, multinucleate giant cells (MGCs) organised into micro-granulomas in follicle centres and/or peritrabecular spaces and interstitial pneumonia often complicated by necrosis and fibrinous exudate. The diagnosis of PMWS and PCVAD is hampered by numerous sub-clinical infections. Nowadays, IHC and ISH are considered the gold standard for detecting PCV2 as part of the diagnosis of PCVAD (Ghebremariam and Gruys 2005). The concomitant presence of three disease characteristics, i.e. clinical signs and especially histological lesions, and PCV2 within the lesions (in lymphoid tissue and/or lung) are the hallmarks for PCVAD diagnosis (Ghebremariam and Gruys 2005; Sarli et al. 2009; Segalés 2002; Sorden 2000). However, since clinical data in wild boar are usually not available, the diagnosis can only depend on pathological findings and demonstration of PCV2 within lesions (Schulze et al. 2004).

The present study aimed to collect information on PCV2 infection and PCVAD in three wild boar populations in Northern and Central Italy, and evaluate the use of IHC and IF as tools for epidemiological PCV2 studies in this species.

\section{Materials and methods}

Sample collection

Between November 2006 and March 2008, 348 shot wild boar (174 females and 174 males) were sampled in the provinces of Bologna $\left(44^{\circ} 00^{\prime} \mathrm{N}, 11^{\circ} 00^{\prime} \mathrm{E}\right)$ (86 subjects) and Padua $\left(45^{\circ} 14^{\prime} \mathrm{N}, 11^{\circ} 45^{\prime}\right.$ E) (62 subjects in Regional Park of Colli Euganei) in Northern Italy and Pisa $\left(43^{\circ} 45^{\prime} \mathrm{N}\right.$, $10^{\circ} 26^{\prime} \mathrm{E}$ ) in Central Italy (200 subjects). Complete clinical and macroscopic data were not always recorded during sampling, but the weights were reported together with data on mortality (no case) within the areas under study. The collected tissues, mostly sampled by hunters or technicians, were 485 lymph nodes (superficial inguinal, systematically sampled for each animal, retromandibular and tracheobronchial) and 65 pulmonary and 61 iliac specimens. The animals, ranging from 1 to more than 38 months of age, estimated by tooth-eruption according to Monaco et al. (2003), were divided into four age classes: "a" (1-6 months, 66 subjects), "b" (7-12 months, 87), "c" (13-24 months, 141) and "d" (over 24 months, 54).

\section{Histopathology}

Tissue samples were fixed in $4 \%$ buffered formalin, paraffin-embedded and routinely stained with haematoxylin and eosin (H\&E). Gram, Periodic acid-Schiff (PAS) and Ziehl-Neelsen (Z-N) stains were also performed in some selected cases (i.e. granulomatous lymphadenitis) to disclose bacteria, mycetes or acid-fast bacteria, respectively.

\section{Immunohistochemistry}

Four-micrometre-thick sections were immunohistochemically stained using a monoclonal as a primary antibody to PCV2 (Mab F217) kindly provided by the Dr. Gordon Allan (Veterinary Sciences Division, Department of Agriculture and Rural Development, Belfast, UK). Briefly, the sections were de-waxed and rehydrated through a series of graded alcohols. The endogenous peroxidases were inhibited with hydrogen peroxide $0.3 \%$ in methanol for $30 \mathrm{~min}$; antigen retrieval was achieved by protease XIV $(0.05 \%)$ at $37^{\circ} \mathrm{C}$, and sections were rinsed in PBS. The primary antibody (Mab F217) was added to the sections at 1:200 dilution and incubated overnight at $4^{\circ} \mathrm{C}$. Then the sections were incubated with the secondary antibody and subsequently with the streptavidin-biotin-peroxidase complex (DAKO LSAB kit peroxidase). The reaction was revealed using diaminobenzidin $(0.04 \%$ for $10 \mathrm{~min})$ as chromogen. The sections were counterstained with Papanicolau haematoxylin, dehydrated and mounted with dibutylphthalate-xylene (DPX, Fluka, Buchs, Switzerland). 
Lymphoid tissue of a piglet with spontaneous PMWS confirmed by PCR and in situ hybridization served as a positive control. As negative control, an antibody of the same isotype (IgG1) as the primary antibody but of irrelevant specificity was employed for each sampled tissue.

\section{Immunofluorescence}

For immunofluorescence, a commercial polyclonal antibody fluorescein isothiocyanate conjugated (FITC) directed against PCV-2 was used directly on lymph node sections. Samples were de-waxed, rinsed in PBS and incubated for one hour in a moist chamber, with $100 \mu 1$ of antibody diluted 1:50 with the buffer. Sections were then rinsed three times in PBS and once in distilled water, mounted and observed with a fluorescent microscope. As positive controls, lymph node sections of a naturally PCV-2 infected pig were used. Negative controls were obtained with the omission of the FITC antibody for each sampled tissue.

In situ hybridization

ISH was performed on two cases, both IHC and IF positive, to prove the specificity of results of the two methods in this species. Four-micrometre-thick sections were de-waxed in xylene, rehydrated in graded alcohols and finally immersed in a TBS-based buffer. Digestion was performed with $0.3 \%$ pepsin in the TBS-based buffer $(\mathrm{pH} \mathrm{2})$ for $10 \mathrm{~min}$ at $37^{\circ} \mathrm{C}$. Slides were then washed twice in the buffer and incubated with $100 \%$ formamide (J.T. Baker, Phillipsburg, NJ, USA) for $5 \mathrm{~min}$ at $105^{\circ} \mathrm{C}$ in a thermal-cycler (Primus 96, MWG BioTech, Ebersberg, Germany). Sections were subsequently hybridised with a PCV2-specific, single-stranded oligonucleotide DNA probe, hybridising a tract of the viral genome encoding the replication-associated protein Rep (Kennedy et al. 2003). The probe was labelled at the $3^{\prime}$ end with digoxigenin (MWG Bio-Tech, Ebersberg, Germany) (sequence: 5'-CCT TCC TCA TTA CCC TCC TCG CCA ACA ATA AAA TAA TCA AA- $3^{\prime}$ ). The slides were first incubated at $105^{\circ} \mathrm{C}$ for $5 \mathrm{~min}$ and then at $37^{\circ} \mathrm{C}$ for $60 \mathrm{~min}$. To guarantee complete coupling between the target nucleic acid and the probe, high stringency washes were performed with saline sodium citrate buffers. The digoxigenin-labelled sections were subsequently stained using an anti-digoxigenin antibody conjugated to alkaline phosphatase (Roche Diagnostics, Mannheim, Germany). Nitroblue tetrazolium dye (NBT) was used for colour developing. Dye reduction to insoluble blue-black formazan indicated areas of probe hybridization. Fast Green $1.5 \%$ (Sigma, St. Louis, MO, USA) was used to counterstain the sections that were further dehydrated in graded alcohols, then in acetone-xylene and mounted with DPX.

\section{Diagnostic histological criteria}

Diagnostic interpretation was based on the following steps, as reported by Sarli et al. (2009) for the pig.
Fig. 1 Wild boar: superficial inguinal lymph node. a Multinucleate giant cells (MGCs) in a germinal centre, $\mathrm{H} \& \mathrm{E}, \times 20$. b Positive immunoreaction to PCV2 in the cytoplasm of MGCs and histiocytes, $\times 20$. c Cytoplasm of PCV2 infected histiocytes within a germinal centre shows an intense green fluorescent stain, $\times 20$. d PCV2 DNA (blue stain) is detected in the cytoplasm of MGCs and histiocytes in germinal centre (ISH, chromogen NBT), $\times 20$
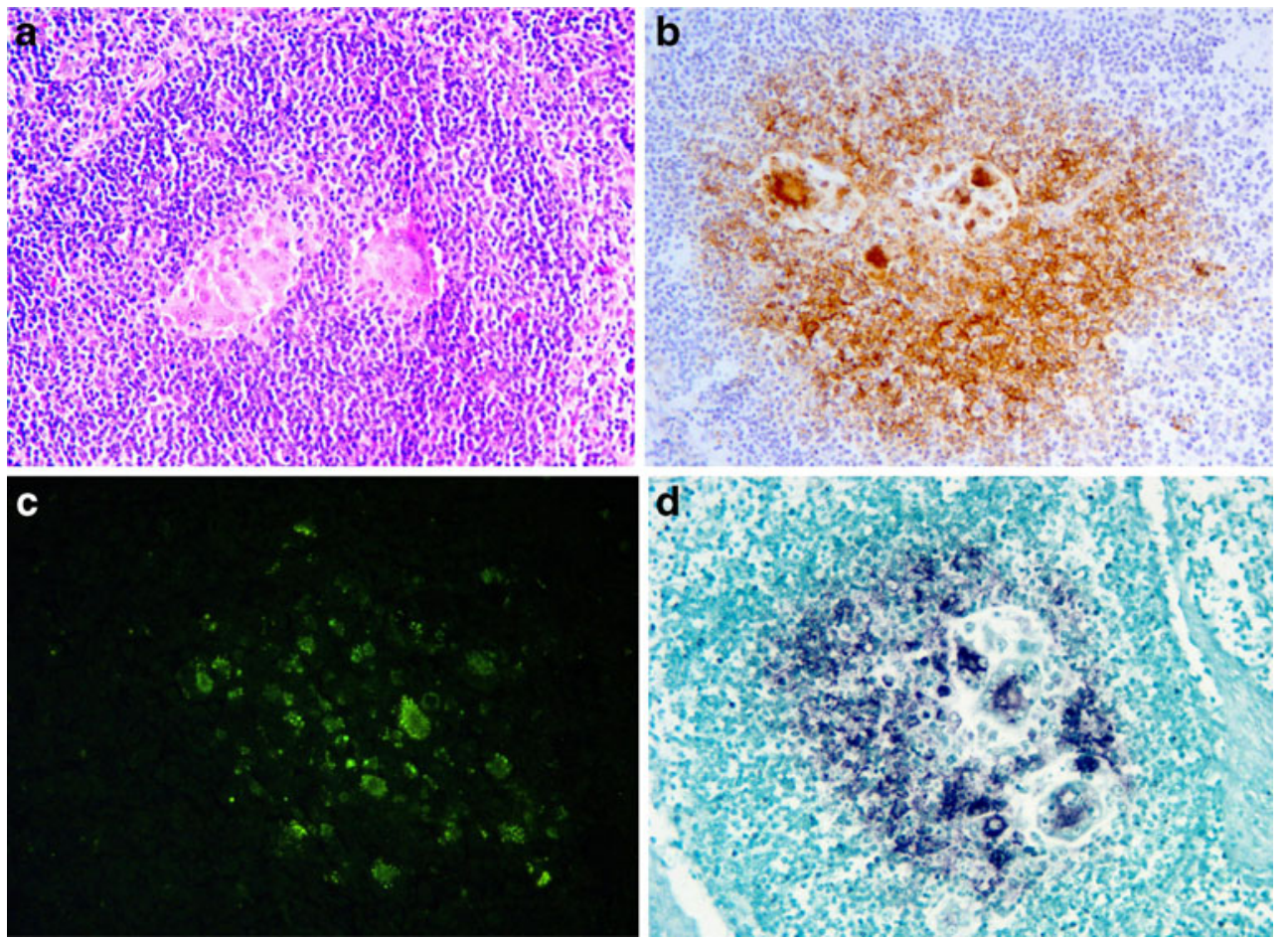


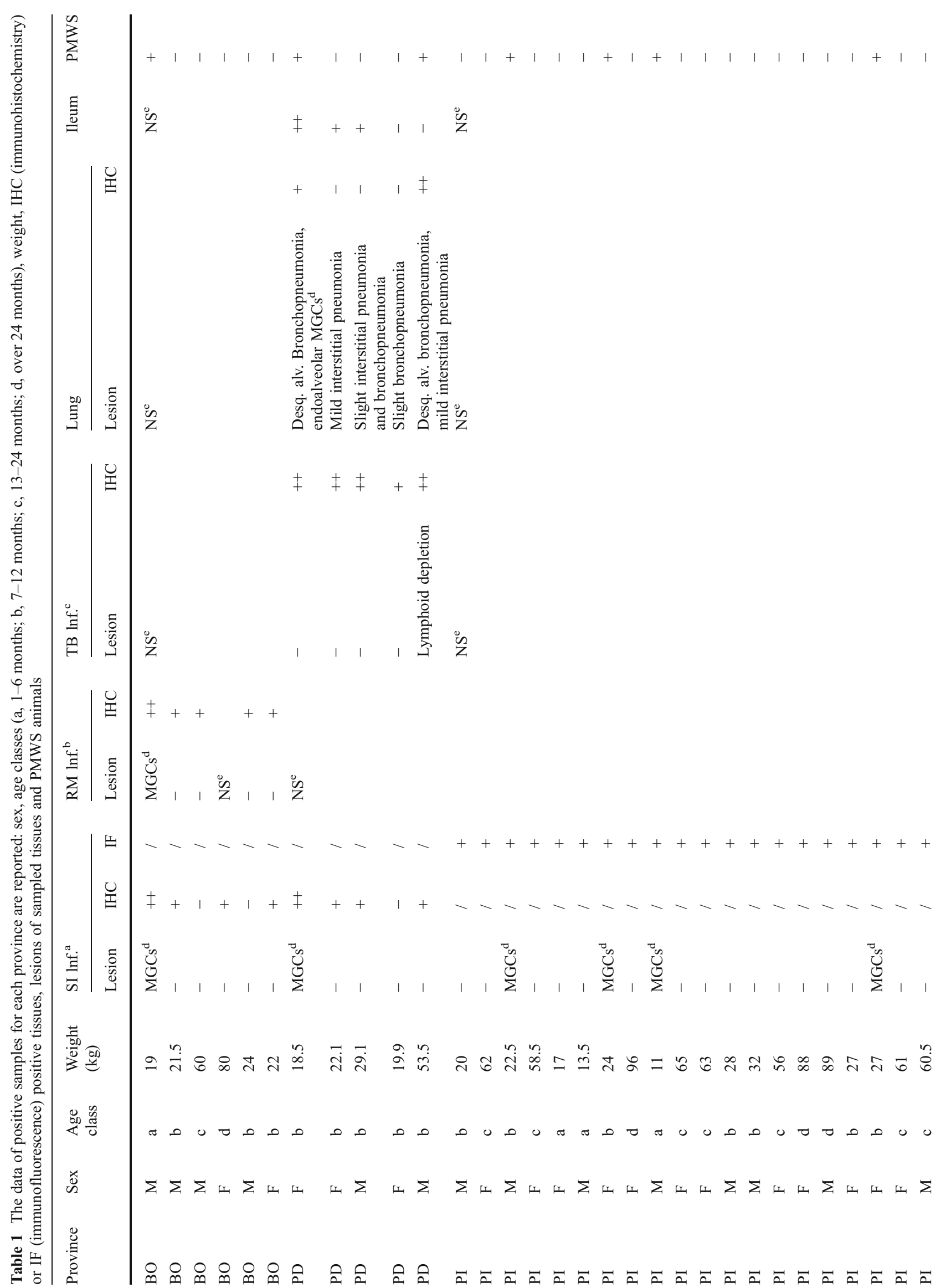




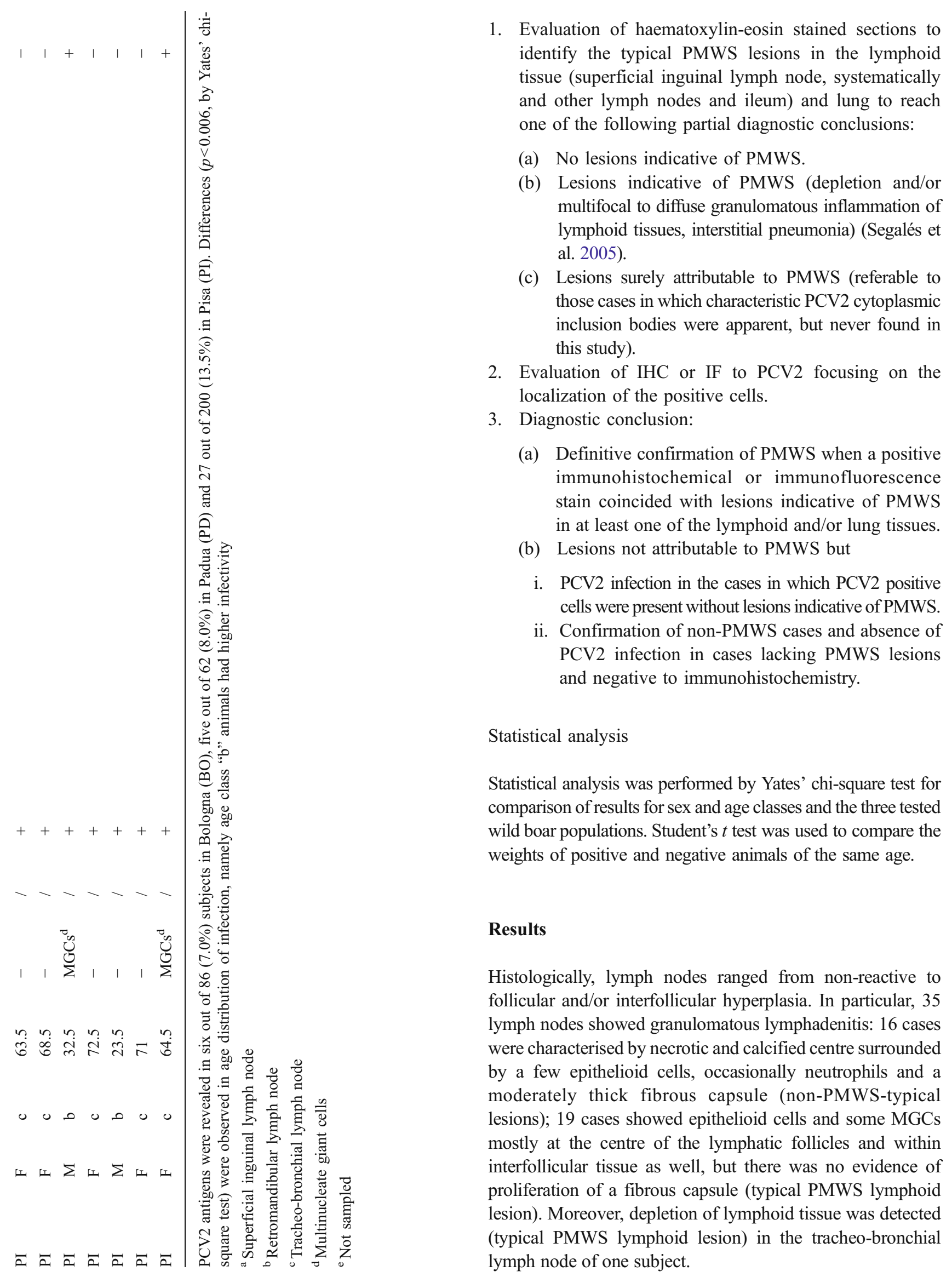


Gram, PAS and Z-N stains did not disclose any aetiological agents. Eleven lungs of 65 available for the study showed adults and/or larvae of nematoda within bronchial and bronchiolar lumina, whereas 22 pulmonary specimens were characterised by BALT activation that in 12 cases formed ectopic lymphoid nodules (Kisselev's nodules). Focal to multifocal bronchopneumonia associated with desquamative alveolitis was noted in six animals. In addition, 27 lungs had a light to moderate and focal to multifocal interstitial pneumonia. No lesions were recorded in ileum samples (61 available).

Both PCV2 IHC/IF-positive cases tested by ISH (Fig. 1) confirmed the presence of PCV2 DNA: the samples showed specific intracytoplasmic spots in histiocytes of follicular cores and, to a lesser extent, of interfollicular tissue.

IHC for PCV2 of Northern Italy was positive in 11 animals (five females and six males) out of $148(7.4 \%)$ : six of 86 $(7.0 \%)$ in Bologna and five of $62(8.0 \%)$ in Padua. The infection prevalence (tested by IF) was higher in Pisa with 27 positive subjects out of 200 (13.5\%, 10 males and 17 females). However, no significant differences were assessed by Yates' chi-square test among the three sampled populations. The IHC and IF pattern of PCV2-positive samples showed a moderate to high amount of antigen in the cytoplasm of follicular and/or interfollicular histiocytes in lymph nodes and/or MALT (mucous-associated lymphoid tissue) of the ileum and lung. The lung showed positivity of interstitial macrophages in two cases. In all (Table 1), only nine animals were diagnosed as PMWS subjects, because lesions and viral antigen coexisted in at least one tissue sample (29 of 38 positive animals did not present PMWS-typical lesions, and 10 out of 19 animals showing PMWS-typical lesions were IHC and IF PCV2 negative). In particular, seven wild boar showed MGCs and micro-granulomas in positive lymph nodes. One animal had moderate lymphoid depletion in positive lymph nodes, and desquamative alveolites associated with acute bronchopneumonia in moderately positive lungs. Another suffered from desquamative alveolitis with positive endoalveolar MGCs. No tissue showed PMWS-typical lesions in the remaining 29 positive cases, suggesting only PCV2 infection.

Summarising, PCV2 infection was proved with the following age-class distribution: "a" four out of 66 (6.06\%), "b" 17 out of $87(19.54 \%)$, "c" 13 out of $141(9.21 \%)$ and "d" four out of 54 (7.4\%) (Table 1). Differences in positivity with age-class distribution were statistically significant $(p<0.006)$ namely higher in the animals belonging to the " $\mathrm{b}$ " age class, i.e. 7-12 months. In addition, in the class "b" of Bologna and Padua wild boars (for which month step of age was recorded), a significant higher positivity $(p<0.006)$ was assessed by comparing only animals aged 7 to 8 months to the others of the same class (7/21 vs $1 / 35)$. No differences were disclosed comparing sex or weights between positive and negative animals.

\section{Discussion}

This is the first report of PCV2 infection and PMWS in wild boar in Northern Italy and in Italy, respectively. Together with the papers by Verin et al. (2007) and Petrini et al. (2009) on PCV2 diffusion in central Italy, the present study suggests that PCV2 and PMWS is widespread and endemic among the wild boar populations in Italy.

Complete clinical and macroscopic data on wildlife are usually not available as was the case in our study. However, the diagnosis of PMWS in wild boar can depend on the demonstration of PCV2 within lesions (Schulze et al. 2004). One study (McNeilly et al. 1999) found that IHC for the detection of PCV2 antigen in formalin-fixed, paraffin-waxembedded tissue was more sensitive than PCV2 DNA detection by ISH, and the positive ISH in two IHC and IF positive cases as in the positive control confirmed the specificity of IHC and IF. Moreover, ISH is a more complex and expensive technique than IHC (Chae 2004).

The nine cases diagnosed as PMWS in our investigation belonged to age class "a" (two animals), "b" (six animals) and "c" (one animal); thus, only two animals were under 6 months of age (16-20 weeks old). The two positive subjects show a similar average age as the PMWS pigs described by Segalés et al. (2005); the remainder had late PMWS manifestations. A delay in developing PMWS signs and lesions was also reported by Schulze et al. (2004) and Vicente et al. (2004), recording the disease in wild boar aged more than 40 weeks. This may be due to the later weaning age of wild boar in nature (Correa et al. 2006) or to the absence of intensive management procedures such as vaccinations and other stressors.

The present study found 7- to 12-month-old animals in group "b" (17 out of 87) statistically more affected by PCV2 infection than other age classes. In particular, the results among the Northern Italy population (Bologna and Padua) showed a peak of positive cases among animals aged 7 to 8 months (seven out of 21) that were more severely infected than other animals (9-12 month old) $(p<0.006)$, suggesting that wild boar aged 7 to 8 months are the most important for the epidemiology of PCV2 infection. This result reflects the findings of Delogu et al. (2008) who reported a lower seroprevalence among group "b" animals, attributing it to the decay of maternal antibodies in boar of this age. This may explain the higher rate of infection encountered in "b" group animals in the present study. The overall prevalence of our samples $(10.9 \% ; 38 / 348)$ was lower than values reported in other countries: $23-58 \%$ in Spain (Vicente et al. 2004), 35.6\% in Belgium (Sanchez et al. 2001), 43\% in Czech Republic (Sedlak et al. 2008), 20.5\% in Hungary (Cságola et al. 2006) and 25\% in Slovenia (Toplak et al. 2004). These numeric differences may be due to the tests used, IHC or IF vs serology or PCR, respectively. 
PCV2 infection and blood levels of PCV2 antibodies in wild boar are known to be associated with the density of animals in the area or in intensively managed populations (Vicente et al. 2004). The three different populations in our study were reported to have a similar density: 10 animals/100 ha in Bologna (Canetti, personal communication), 10.7 \pm 2.8 animals/100 ha in Padua (Scacco et al. 2008), 10-12 animals/ 100 ha in Pisa (unpublished data; "Annual statistical data of hunting” (2006), ATC (Ambito Territoriale di Caccia) Pisa 14 and 15). The slight differences in prevalence of infection, albeit non-significant, merit some consideration, such as the different methods of sample evaluation (the evaluation of IF is more subjective than IHC), and orography, class distribution of animal populations and presence of free-range pigs for which no information was available in this study.

Wild boar is a potential reservoir of several viruses for the domestic swine, such as classical swine fever virus (Rossi et al. 2005), Aujeszky disease virus (Lari et al. 2006; Vicente et al. 2005) and bovine viral diarrhoea virus (Zupancic et al. 2002), but the contrary seems to occur for PCV2 (Ruiz-Fons et al. 2008). In fact, a serological survey proved high infection pressure with prevalence close to $100 \%$ in pigs worldwide (Segalès and Domingo 2002), and PMWS also on Italian farms (73.8\%, Sarli et al. 2009), and these prevalence values are higher than those described in wild species (Sanchez et al. 2001; Vicente et al. 2004). Moreover, this was confirmed by an American study (Corn et al. 2009) that proved higher seroprevalences of feral swine populations in high-density commercial swine production regions than in transitional swine regions with very low swine density (519.3 vs 1.5 swine per square kilometre).

The present results suggest that although PCV2 is endemic, it should not play a role in the dynamics of tested populations (no reported abnormal mortalities and no recordable clinical signs in affected animals). In addition, both IHC and IF can be used successfully to survey PCV2 in wild boar as they both prove not only the infection but also the disease in the tested population.

Acknowledgements The authors thank M. Gallo and the Regional Park of Colli Euganei, the ATC BO4 and 3 (Bologna 4 and 3, respectively) and PI14 and 15 (Pisa 14 and 15, respectively) for the kind help of their hunters. They also thank F. Riga and the Istituto Superiore per la Protezione e la Ricerca Ambientale (ex Istituto Nazionale per la Fauna Selvatica). The authors are grateful to A. Collins for English language editing of the text.

\section{References}

Chae C (2004) Postweaning multisystemic wasting syndrome: a review of aetiology, diagnosis and pathology. Vet J 168:41-49

Corn JL, Cumbee JC, Barfoot R, Erickson GA (2009) Pathogen exposure in feral swine populations geographically associated with high densities of transitional swine premises and commercial swine production. J Wildl Dis 45:713-721

Correa AMR, Zlowtoski P, Rozza DB, Borba MR, Leal JS, Cruz CEF, Driemeier D (2006) Postweaning multisistemic wasting syndrome in farmed wild boars (Sus scrofa) in Rio Grande do Sul. Pesq Vet Bras 26:154-156

Cságola A, Kecskeméti S, Kardos G, Kiss I, Tuboly T (2006) Genetic characterization of type 2 porcine circoviruses detected in Hungarian wild boars. Arch Virol 151:495-507

Delogu M, Ostanello F, Martin AM, Lelli D, Frasnelli M, Marzadori F, Raffini E, De Marco MA (2008) Infezione da PCV2 nel cinghiale: dinamica anticorpale in una popolazione monitorata in un'area protetta (2002-2006). Proc of IV Workshop Nazionale di Epidemiologia Veterinaria, Dicembre 11-12, Roma, p. 91. http://www.iss. it/binary/publ/cont/0393-5620_2008_I_08_C12.1227856940.pdf

Ellis J, Spinato M, Yong C, West K, McNeilly F, Meehan B, Kennedy S, Clark E, Krakowka S, Allan GM (2003) Porcine circovirus 2associated disease in Eurasian wild boar. J Vet Diagn Invest 15:364-368

Ghebremariam MK, Gruys E (2005) PMWS in pigs with particular emphasis on the causative agent, the mode of the transmission, the diagnostic tools and the control measures. A review. Vet Q $27: 105-116$

Kennedy S, Segalés J, Rovira A, Scholes S, Domingo M, Moffett D, Meehan B, O'Neill R, McNeilly F, Allan G (2003) Absence of evidence of porcine circovirus infection in piglets with congenital tremors. J Vet Diagn Invest 15:151-156

Knell S, Willems H, Hertrampf B, Reiner G (2005) Comparative genetic characterization of Porcine circovurs type 2 samples from German wild boar populations. Vet Microbiol 109:169-177

Harding JCS (1996) Postweaning multisystemic wasting syndrome (PMWS), preliminary epidemiology and clinical findings. Proc of the West Canadian Association of Swine Practitioners, p. 21

Harding JCS (2004) The clinical expression and emergence of porcine circovirus 2. Vet Micr 98:131-135

Lari A, Lorenzi D, Nigrelli D, Brocchi E, Faccini S, Poli A (2006) Pseudorabies virus in European wild boar from central Italy. J Wildl Dis 42:319-324

Lipej Z, Segalés J, Jemersic L, Olver A, Roic B, Novosel D, Mihaljevic Z, Manojlovic L (2007) First description of postweaning multisystemic wasting syndrome (PMWS) in wild boar (Sus scrofa) in Croatia and phylogenetic analysis of partial PCV2 sequences. Acta Vet Hung 55:389-404

McNeilly F, Kennedy S, Moffet D, Meehan BM, Foster JC, Clarke EG, Ellis JA, Haines DM, Adair BM, Allan GM (1999) A comparison of in situ hybridization and immunohistochemistry for the detection of a new porcine circovirus in formalin-fixed tissue from pigs with post-weaning multisystemic wasting syndrome (PMWS). J Vet Meth 80:123-128

Monaco A, Franzetti B, Pedrotti L, Toso S (2003) Linee guida per la gestione del Cinghiale. Min. Politiche Agricole e Forestali-Ist. Naz. Fauna Selvatica, pp 116

Oppriessnig T, Meng X-J, Halbur PG (2007) Porcine circovirus type 2-associated disease: update on current terminology, clinical manifestations, pathogenesis, diagnosis, and intervention strategies. J Vet Diagn Invest 19:591-615

Park JS, Kim J, Ha Y, Jung K, Choi C, Lim JK, Kim H, Chae C (2005) Birth abnormalities in pregnant sows infected intranasally with porcine circovirus 2. J Comp Pathol 132:139-144

Petrini S, Barocci S, Gavaudan S, Villa R, Briscolini S, Sabbatini M, Mattozzi C, Barchiesi S, Salamida S, Ferrari M, Paniccià M, Pezzotti G (2009) Detection of porcine circovirus type 2 (PCV2) from wild boars in central Italy. E J Wildl Res 55:465. doi:10.1007/s10344-009-0262-7

Rose N, Blanchard P, Larour G, Le Deguerher G, Eveno E, Jolly JP, Oler A, Le Dimna M, Jestin A, Madec F (2002) Post-weaning 
multisystemic wasting syndrome (PMWS) in France: serological profiles of affected virus non-affected herds and preliminary analytical epidemiology. Pig J 50:124-134

Rossi S, Fromont E, Pontier D, Cruciére C, Hars J, Barrat J, Pacholek X, Artois M (2005) Incidence and persistence of classical swine fever in free-ranging wild boar (Sus scrofa). Epidm Infect 133:559-568

Ruiz-Fons F, Segalés J, Gortazar C (2008) A review of viral diseases of the European wild boar: effects of population dynamics and reservoir role. Vet J 176:158-169

Sanchez R, Nauwynck H, Pensaert M (2001) Serological survey of porcine circovirus 2 antibodies in domestic and feral pig populations in Belgium. Proc. ssDNA viruses of plants, birds, pigs and primates. St.Malo (France), 122

Sarli G, Ostanello F, Morandi F, Fusaro L, Gnudi M, Bacci B, Nigrelli A, Alberali L, Dottori M, Vezzoli F, Barigazzi G, Fiorentini L, Sala V, Leotti G, Joisel F (2009) Application of a protocol for the diagnosis of PMWS in Italy. Vet Rec 164:519-523

Scacco M, Calmanti R, Franzetti B, Riga F, Bado F (2008) Comparison of distance sampling and faecal pellet count to estimate wild boar density. 7th International Symposium on Wild Boar (Sus scrofa) and on Sub-order Suiformes. Sopron (Hungary), 28-30 August

Schulze C, Segalés J, Neumann G, Hlinak A, Calsamiglia M, Domingo M (2004) Identification of postweaning multisystemic wasting syndrome in European wild boar (Sus scrofa). Vet Rec 154:694-696

Sedlak K, Bartova E, Machova J (2008) Antibodies to selected viral disease agents in wild boar from Czech Republic. J Wildl Dis 44:777-780

Segalés J (2002) Update on postweaning multisystemic wasting syndrome and porcine dermatitis and nephropathy syndrome diagnostics. J Swine Health Prod 10:277-281

Segalès J, Domingo M (2002) Postweaning multisystemic wasting syndrome (PMWS). A review. Vet Q 24:109-124
Segalés J, Rosell C, Domingo M (2004) Pathological findings associated with naturally acquired porcine circovirus type 2 associated disease. Vet Micr 98:137-149

Segalés J, Allan GM, Domingo M (2005) Porcine circovirus diseases. Anim Health Res Rev 6:119-142

Sofia M, Billinis C, Psychas V, Birtsas P, Sofianidis G, Leontides L, Knowles N, Spyrou V (2008) Detection and genetic characterization of porcine circovirus 2 isolates from the first cases of postweaning multisystemic and wasting syndrome in wild boars in Greece. J Wildl Dis 44:864-870

Sorden SD (2000) Update on porcine cicovirus and postweaning multisystemic wasting syndrome. J Swine Heath Prod 8:133-136

Toplak I, Grom J, Hostnik P, Barlič-Maganja D (2004) Phylogenetic analysis of type 2 porcine circoviruses identified in wild boar in Slovenia. Vet Rec 155:178-180

Verin R, Ricci M, Taccini E, Poli A (2007) PCV2 diffusion in the wild boar (Sus scrofa) population from the province of Grosseto and Pisa. Proc IV National Meeting of AIPVet, p 126

Vicente J, Segalés J, Höfle U, Balasch M, Plana-Duràn J, Domingo M, Gortàzar C (2004) Epidemiological study on porcine circovirus type 2 (PCV2) infection in European wild boar (Sus scrofa). Vet Res 35:243-253

Vicente J, Ruiz-Fons F, Vidal D, Höfle U, Acevedo P, Villanúa D, Fernández-de-Mera IG, Martín MP, Gortázar C (2005) Serosurvey of Aujeszky's disease virus infection in European wild boar in Spain. Vet Rec 156:408-412

Zupancic Z, Jukic B, Lojkic M, Cac Z, Jemersic L, Staresina V (2002) Prevalence of antibodies to classical swine fever, Aujeszky's Disease, porcine reproductive and respiratory syndrome, and bovine viral diarrhoea viruses in wild boars in Croatia. J Vet Med Ser B 49:253-256 